\title{
Comparative Politics and Rational Choice: A Review Essay
}

\section{Citation}

Bates, Robert H., Albert Breton, Gianluigi Galeotti, Pierre Salmon, Ronald Wintrobe, Youssef Cohen, Josep M. Colomer, et al. 1997. “Comparative Politics and Rational Choice: A Review Essay." The American Political Science Review 91 (3) (September): 699.

\section{Published Version}

doi: $10.2307 / 2952085$

\section{Permanent link}

http://nrs.harvard.edu/urn-3:HUL.InstRepos:12211510

\section{Terms of Use}

This article was downloaded from Harvard University's DASH repository, and is made available under the terms and conditions applicable to Other Posted Material, as set forth at http:// nrs.harvard.edu/urn-3:HUL.InstRepos:dash.current.terms-of-use\#LAA

\section{Share Your Story}

The Harvard community has made this article openly available.

Please share how this access benefits you. Submit a story.

Accessibility 


\section{Comparative Politics and Rational Choice: A Review Essay ROBERT H. BATES Harvard University}

Nationalism and Rationality. Edited by Albert Breton, Gianluigi Galeotti, Pierre Salmon, and Ronald Wintrobe. Cambridge: Cambridge University Press, 1995. 323p. \$54.95.

Radicals, Reformers, and Reactionaries: The Prisoner's Dilemma and the Collapse of Democracy in Latin America. By Youssef Cohen. Chicago: University of Chicago Press, 1994. 186p. \$34.95 cloth, $\$ 14.95$ paper.

Game Theory and the Transition to Democracy: The Spanish Model. By Josep M. Colomer. Brookfield, VT: Edward Elgar, 1995. 134p. \$70.00.

Structure and Policy in Japan and the United States. Edited by Peter F. Cowhey and Mathew D. McCubbins. Cambridge: Cambridge University Press, 1995. 292p. \$59.95 cloth, \$18.95 paper.

Private Truths, Public Lies: The Social Consequences of Preference Falsification. By Timur Kuran. Cambridge, MA: Harvard University Press, 1995. 423p. $\$ 46.95$ cloth, $\$ 18.95$ paper.

Making and Breaking Governments: Cabinets and Legislatures in Parliamentary Democracies. By Michael Laver and Kenneth A. Shepsle. Cambridge: Cambridge University Press, 1996. 301p. \$59.95 cloth, \$18.95 paper.

Origins of a Spontaneous Revolution: East Germany 1989. By Karl-Dieter Opp, Peter Voss, and Christiane Gern. Ann Arbor: University of Michigan Press, 1995. 280p. $\$ 49.50$.

I $\mathrm{n}$ a review of the literature on comparative politics, provocatively entitled "Paradigms and Sand Castles," Barbara Geddes (1991) bemoans the transient nature of the field. Rather than being rejected, theories are being discarded, she declares; as new phenomena capture our attention, so do new approaches to the study of politics. The field thus appeairs to be driven by fads. Geddes concludes her unflattering portrayal by pointing to a series of new entrants into the study of comparative politics, including rational choice theory.

As evidenced by the books under review, in the short time since the Geddes essay, the rational choice approach has indeed infiltrated the field. Consistent with the tendies that Geddes described and decried, compelling political events provide the impetus for its invasion: the fall of communism, the rise of democracy, and the resurgence of ethnic conflict. The questions this reviewer therefore confronts are: Do these books constitute evidence of further faddism? Or do they represent efforts to contribute to the cumulative creation of knowledge? And what are the strengths and

Note: The author wishes to thank David Laitin, Mark Lichbach, Susan Stokes, Barry Weingast, and two anonymous referees for their comments and criticisms. The faults that remain are his alone. weaknesses of rational choice approaches to the study of politics, as exemplified in these volumes?

\section{THE BOOKS}

In addressing such questions, I begin with Breton et al., Nationalism and Rationality. I then turn to works on the fall of communism, then to studies of the rise, fall, and practice of democracy. I conclude with a critique and evaluation.

\section{Ethnicity}

For individuals, the costs of violence often appear to outweigh the benefits; and, for society as a whole, violence, though costly, merely redistributes rather than creates resources. Violence is therefore destructive, and ethnic violence particularly so. For these and other reasons, ethnic conflict poses fundamental challenges to any theory based on the premise of rationality. Thus, the recent reassertion of ethnic claims stands as a challenge to the recent rise of rational choice theory in the comparative study of politics (as was recognized by Weiner and Huntington 1987).

In earlier works, Breton (1964) and Gellner (1979) deployed the tools of political economy, as they understood them, to address the phenomenon of ethnicity. Nationalism and Rationality celebrates their contributions and provides new ones. As the arguments of Breton and Gellner have since long been absorbed by other scholars, I concentrate on the contributions by others.

One is by Russell Hardin (whose own recent book, One for All, 1995, fully warrants independent review). Arguing against so-called primordialist theories, Hardin agrees that ethnic groups promote socially irrational behavior; but, he insists, ethnic identification is the result of individually rational decisions. Within ethnic boundaries, individuals find it beneficial to cooperate, that is, to take actions beneficial for the group, since they expect other members to engage in such behavior. But this logic may not apply across groups. The gains of one group may come at the expense of another, and what members of one group may regard as cooperation, members of another may experience as predation. The boundary of group membership may form a locus of conflict, and in the midst of antagonism, expectations of hostility may become self-confirming. Hardin thus views ethnic identification as a result of choice making in environments in which expectations need not be revised. "The group may [then become] instrumentally good for its members, who may tend ... to think it is inherently, not merely contingently, good," he argues (p. 41), while nonmembers may come to view the group, and its loyalists, as arrogant, privileged, and threatening. Beliefs about good and evil, cooperation 
and defection, become rational beliefs. Ethnic coordination therefore leads not only to inclusion but also to exclusion and conflict.

Wintrobe's paper also deserves a wide audience. Building an ethnic community, Wintrobe stresses, requires investments in human capital. Property rights are costly to create and enforce; by investing resources in relationships, people, in effect, render themselves vulnerable, thereby offering assurances that they will honor their commitments to others. An ethnic group contains a dense set of such relationships; defection from its ranks would trigger costly responses; and membership therefore provides the underpinnings for trust and honorable behavior. The result is that it often becomes easier to transact within rather than across ethnic groups. Their subjective properties as communities thus become objectively valuable. And this is particularly the case when other means for enforcing contracts, such as the state, weaken or disintegrate, as has taken place in Africa, Eastern Europe, and the former Soviet Union.

In his essay, Coleman interprets membership as an entitlement: Ethnic groups, like nations, allocate rights, he argues, and people seeking to defend their entitlements make private sacrifices for the collectivity. In another essay, Congleton applies club theory to the study of ethnic groups. Taken together, the papers in this volume provide a series of analytically motivated insights into the rational foundations for the formation of ethnic groups and for the contemporary resurgence of ethnic nationalism.

\section{The Fall of Communism}

As revealed in earlier works (e.g., Weiner and Huntington 1987), the rise of ethnic nationalism provoked a reaffirmation of the power of cultural approaches to politics. Applying rational choice techniques to this phenomenon, Hardin, Wintrobe, and others contest ground already occupied by others. No received wisdom dominates the interpretation of the fall of communism, however. In Origins of Spontaneous Revolution, a very able group of scholars ventures into this open terrain; deploying standard social science methods, they explore the role of citizen activists in the overthrow of the government of East Germany. In Private Truths and Public Lies, Timur Kuran, an adventurous theorist, joins them. The first ponder, and the second uses, forms of rational choice theory while exploring the collapse of communism.

Origins of Spontaneous Revolution represents a lucidly conceived and presented examination of citizen participation in the "Monday Demonstrations" that precipitated the collapse of Communist Germany. In methods and purpose, the book resembles Inkele's (1961) study of public opinion in the Soviet Union. While inspired by the classics in political sociology, Origins addresses key issues in rational choice. It seeks to explain why citizens participated in acts that were costly, potentially ineffective, and subject to free riding.

Origins rejects the sufficiency of structuralist explanations. The authors adduce persuasive counters to arguments based upon external constraints, such as the power of the USSR, or domestic structures, such as the power of the church or the weakness of the Communist Party. Drawing upon 1,200 interviews with randomly selected subjects and 200 purposefully selected respondents, the authors instead stress the central significance of individual choice. The revolution, they argue, represented the cumulative effect of individual decisions to embrace the risks of public opposition to an incumbent regime.

Although endorsing methodological individualism, and therefore breaking with a central element of the sociological tradition, the authors remain unwilling to subscribe to an instrumentalist perspective. They stress, for example, that people who faced greater risks of sanctions nonetheless participated more frequently in demonstrations. More telling is their evidence against free riding: Endorsing a norm of political unity and the belief that each individual's behavior can make a difference, the participants were impelled to revolutionary acts, they find, by a sense of moral obligation.

Persuaded by the evidence that while people acted as individuals, they were normatively driven, the authors flirt with a notion of "thick" rationality (Ferejohn 1991), in which the participants behave rationally, given their normative commitments. Alternatively, they appear to reason in terms of "meta-norms" (Axelrod 1986, Taylor 1987), by which it becomes rational to act, knowing that others subscribe to a norm of sanctioning failures to do so. When the authors explore the strategic setting within which the revolution transpires, they slip farther into the logic of rational choice. As their analysis makes clear, the strategic setting did not necessarily define a prisoners' dilemma; rather, it defined a coordination game. The more others took part, the stronger were the incentives for additional individuals to join. The implication is clear: Failure to respond to incentives to free ride is perfectly reasonable when such incentives do not exist.

While addressing the same events as Origins, Kuran unabashedly marshals the methods of rational choice. Despite its subtitle, the force of Private Truths, Public Lies does not derive from the analysis of individual preferences; it derives, rather, from the analysis of information. When dissidents remain uncertain of the true preferences of others, Kuran argues, they may well dissimulate regarding their own; they may behave as if they support the incumbent regime. When they learn that others also are disaffected, however, they may then judge it safe to act in accord with their true, underlying preferences and to turn against the government.

If Origins of Spontaneous Revolution calls to mind Inkele's The Soviet Citizen (1961), Kuran's book recalls Schelling's Micromotives and Macrobehavior (1978). It is relentlessly creative; playful, but with a seriousness of purpose; and boldly devoid of the rigorous positivism that informs the more sociologically minded study of Origins.

The information cascades so lucidly exposed by Kuran provide a mechanism that generates the processes described and probed in Origins. In doing so, they account for the way in which public demonstra- 
tions can build, even in the absence of explicit organization, and thereby result in powerful waves of collective dissent. In addition, they offer insight into the circumstances in which such demonstrations fail. The initial starting point can be such that the dynamics will dampen, rather than build; or the distribution of preferences may be such that only demonstrations of an improbably great magnitude will trigger further conversions. Kuran's model thus not only accounts for revolutions that occur but also those that do not. While covering the empirical analysis of Origins, it also accounts for other observations: specifically, for revolutions that fail.

Indeed, Kuran's major objective is to explain political arrangements that, while manifestly illegitimate, nonetheless remain intact. He analyzes Stalinist regimes in Europe and political correctness in the United States. He addresses, in addition, racial discrimination, affirmative action, McCarthyism, and the caste system. Sure to offend, his work also informs. It informs us not only about the subjects that he addresses but also about ways in which to think about them. A model, he shows, provides an abstract account; erasing "proper names" it highlights the logic of explanation. It therefore can be applied not only to the data from which it was derived but also against "out of sample" cases. And, indeed, it is the latter in which it is truly tested. (See King, Keohane, and Verba 1994; Bates et al., n.d.).

\section{Democracy: Its Rise and Demise}

Ethnic nationalism and the fall of communism animate much of the politics of our time. As Geddes forecast, and we have witnessed, they also animate much of our scholarship. Accompanying these forces is a third: the rise of democracy. As evidenced by the work of Colomer and Cohen, it also has attracted the interests of scholars committed to the use of rational choice theory.

Colomer's Game Theory and the Transition focuses on the transition to democracy in Spain, one of the seminal events, according to Huntington (1991), in the third wave of democratization. While the work of Origins brings to mind the classics in political sociology, that of Kuran and the writings of Schelling (1978), it is the work of Riker (e.g., 1982) with which Colomer's book most strongly resonates. As did Riker, Colomer focuses on discrete episodes to explore the way in which political leaders picked their way through unpromising political terrains. Like Riker, he reveals a keen sense of paradox. Extreme outcomes, he illustrates, were avoided, even though preferred by large numbers; for the political agenda was crafted by sophisticated elites, who maneuvered to secure moderate outcomes.

In Origins, Karl-Dieter Opp and associates start with a case and search for a general framework; they lodge, albeit uncomfortably, in the realm of "thick" rationality and coordination games. Kuran starts with a general framework and searches for additional applications. ${ }^{1}$ Colomer, for his part, addresses a single case and

1 Both Opp et al. and Kuran could have greatly benefited from the important contribution of Lohmann (1994). employs but a single framework, based on the analysis of majority rule in a single-dimension issue space with complete information. The strength of Colomer's approach is that it yields a sense of the significance of microlevel details. We see the players clearly, grasp the tactics they employ, and, like them, emerge surprised by the outcomes resulting from their choices. Colomer's approach also reveals how macroevents are generated-often in ways that have not been foreseen-by small, discrete decisions.

While Colomer focuses on the rise of democracy, Cohen focuses on its collapse. Drawing on studies of Brazil in the 1960s and Chile in the 1970s, Cohen argues that moderate leaders in Latin America became trapped by tactical advantages that accrued to political militants. Political preferences and the strategic environment were such that moderates found themselves locked into positions that were collectively irrational but not alterable (i.e., that were in equilibrium). So great were the pressures emanating from the radicals that moderates would surely have faced betrayal had they sought an alliance with conciliatory counterparts in the opposition. Lacking the ability to enforce crossparty alliances, then, the political leadership refrained from moderate settlements. The result was an outcome-the rise of extremists and the collapse of democratic regimes-that they did not choose.

Cohen offers a positive theory of democratic breakdown; he also offers a critique of alternative approaches. Joining Elster (1989) and Przeworski (1985), Cohen criticizes political economic theories for failing to specify the causal mechanism that links economic crisis to political outcome; without such a mechanism, economic theories of politics remain functionalist, he argues. So, too, do noneconomic theories of politics, based upon reified actors, like the state (e.g., Skocpol 1979). Where, as in the case of O'Donnell (1973), such mechanisms are specified, Cohen calls for explanations based not on classes or sectors but on the actions of politicians. Joining Kaufman and others (Collier 1979), Cohen calls for putting the politician, or at least the party system, back in. To explain macroevents, such as the fall of democracy, he argues, the analyst must focus on micropolitics: the choices of politicians and the strategic dilemmas they face in democratic settings.

\section{THE OPERATIONS OF DEMOCRACY}

Rational choice theory enters the study of politics in several forms. One is Madisonian. As developed at the University of Rochester, it applies the tools of rational choice to the study of the self-interested behavior of politicians who seek to fulfill their ambitions for office in the context of democratic institutions. Perhaps the most mature of the several traditions of rational choice analysis, the Madisonian tradition is represented here by two books. The first is Structure and Policy, edited by Peter Cowhey and Mathew McCubbins; the second is Making and Breaking Governments, by Michael Laver and Kenneth Shepsle.

Structure and Policy explores the relationship between political institutions and policy outcomes during 
the era of the Liberal Democratic Party (LDP) in Japan. The book focuses upon the incentives created for legislative incumbents by the rules under which they strove for reelection. On the one hand stood Japan's parliamentary system; on the other was, the system of multimember districts and nontransferable votes. Policymaking in Japan, the contributors argue, reflected the mixture of motives created by these two institutions.

The institutions produced a tension between party leaders and legislators in the Diet. The two groups possessed a common interest in securing majorities for their party at the polls; but they also possessed interests that conflicted over the allocation of these majorities. For a legislator, the larger the vote from the party faithful, the greater was the likelihood of reelection; for the party leaders, the narrower the majorities for each of the candidates, the greater were the number of seats controlled in the Diet. The result of this mixture of motives, the contributors argue, was a characteristic pattern of policymaking: Those policies were preferred that enabled the party leaders to build disciplined political blocs of delegates in the legislature.

As behooves a mature tradition of research, the analysis rests on a formal model (Cox 1990). Building from a theoretical result, Cox, McCubbins, and Rosenbluth document the effect of electoral rules on electoral strategies and party organization. A series of empirical studies then follows, focusing on budgetary expenditures (by McCubbins and Noble) and industrial regulation (by Noll, Cohen, Rosenbluth, and McCubbins). Chapters on foreign policy by Cowhey, Fuki, and Weatherford sustain the point: Public policy is fashioned in ways that reflect the efforts of the political class to manage the tensions within the political organization that keeps them in power.

The progression from problem to model to empirical test marks as well the trajectory of Laver and Shepsle's Making and Breaking Governments. The problem is that of coalition governments: Laver and Shepsle seek to uncover the logic that underlies the stability and composition of cabinets in the postwar democracies of Western Europe. The model represents an adaptation of the winset technology crafted for the analysis of legislative politics in the United States. In parliamentary settings, political parties rather than individual politicians constitute the basic units of analysis, Laver and Shepsle contend. They therefore adapt the conventional specifications of spatial theory, recasting the issue space as a lattice rather than a continuum. Within this new representation, Laver and Shepsle show, winsets that in conventional specifications may contain majority-preferred governments instead stand empty; thus the stability of coalition governments. Moreover, within given configurations of preferences, certain parties become "strong": They reside in the set of cabinets that can overturn the incumbent regime. As strong parties can make-or break-governments, politicians seeking to form governments encounter compelling reasons to give them key portfolios. The model thus offers a theory of the composition of coalition governments as well. Laver and Shepsle analyze an impressive array of data from postwar governments to test propositions derived from their model. They characterize the results as "gratifying"; I would characterize them as impressive.

\section{ANALYSIS}

As argued by Geddes (1991), we should hope to find new contributions being inspired by intellectual debates rather than being triggered by political events. It is significant, therefore, that while addressing contemporary political phenomena, these works also address enduring issues in the discipline. They represent attempts to correct past errors and to achieve deeper understandings. Their authors are not contributors to fashion but rather to scholarship.

Hardin, for example, self-consciously positions his work within a broader research program: He uses the study of ethnicity to debate cultural approaches to politics. Colomer shares Hardin's dissatisfaction with preference-based explanations and provides perhaps the most persuasive rejoinder: Given identical preference configurations, he demonstrates, different outcomes are possible. For this (and other) reasons, then, collective choices cannot be explained on the basis of values. Behaving rationally, people will often end up choosing in ways that are not implied by their preferences. Cultural explanations-and all others that appeal to the sufficiency of values-are therefore unsatisfactory, these authors contend. They must be supplemented with accounts of the procedures by which individual choices aggregate into collective outcomes.

Other authors see rational choice theory as a corrective to "statist" approaches to the study of politics: They endorse a more decentralized model of politics. This position is best illustrated, perhaps, by Cowhey and McCubbins in their analysis of Japan. They provide both a forceful and subtle rejoinder to those who see policy as issuing from the farsighted vision of an elite bureaucracy. Their target is, of course, the statist interpretation that has thus far provided the dominant model of Japanese politics.

The critique of structuralism by Karl-Dieter Opp et al. highlights the significance of this turn; for structuralism, like statism, emphasizes the role of constraint, rather than choice, in political behavior. What makes the departure so striking, of course, is that they study politics in a so-called totalitarian society. Where others saw only binding constraints, political activists perceived room to maneuver, the authors find. Even in totalitarian systems, they contend, there is good reason to view politics as decentralized and manipulable. In the face of such findings-and the evidence provided by the subsequent collapse of the East German regime-the authors move from structuralist forms of sociological theory to an ambivalent embrace of rational choice as a means for studying politics.

The turn to rational choice also represents a reaction against functionalist forms of analysis. Thus, Cohen argues against dependency theory, capitalist logic, and the approach of O'Donnell (1979), each of which views 
authoritarianism as fulfilling a role necessary to the growth of capitalism. Motivating Cohen's criticism is his opposition functionalist explanation, with its emphasis on the social as the appropriate level of analysis. Authoritarianism did not happen in Latin America because the economic system required it, he argues; it was not socially rational. Rather, it resulted from the actions of those unable to transcend the limits of individual rationality.

While focusing on topical issues, the works thus suggest that the movement to rational choice theory represents the outcome of intellectual debate. The movement represents a search for deeper understandings and a reaction to the limitations of previous approaches. The authors address ethnicity, democratization, and the fall of communism; but they remain centrally concerned with the merits and defects of core theoretical positions. The authors seek a decentralized approach, based on microfoundations, in which the collective outcome is derived, albeit often perversely, from choices made by individuals.

\section{EVALUATION}

It is useful to group these works into two schools. One focuses on collective action and the other on collective choice. I would place in the first category the studies of ethnicity and revolution and Cohen's study of the collapse of democracy. In the latter, I would place the work of Colomer, Cowhey and McCubbins, and Laver and Shepsle.

The two schools possess different parentage. The canonical text in the first remains Mancur Olson's The Logic of Collective Action (1977); the central issue, that of the incentives to bear the costs of political action; and the central analytics, the prisoners' dilemma game. In this school, progress has largely taken the form of broadening the analytics to include coordination games-something long advocated by Hardin, but also supported by Kuran and by Karl-Dieter Opp et al.and of deepening them by exploring the prisoners' dilemma in extended form.

Arrow's Social Choice and Individual Values (1951) stands as the canonical text of the collective choice tradition; the central issue is the relationship between individual preferences and collective outcomes; and the use of spatial models provides its basic analytics. Progress in this field has taken a variety of forms, the most relevant for this essay being the analysis of the effect of institutions in generating equlibria in otherwise indeterminate political environments.

Underlying each tradition are technical foundations. The concept of rationality in choice has been rigorously axiomatized, clarifying distinctions of great relevance for both normative and positive analysis (see, for example, Sen 1982). Collective behavior, either in institution-free (collective action) or rule-governed (collective choice) environments, has been studied by applying game theory. Beneath both decision and game theory lie theorems that establish what can and cannot in general be claimed. The rational choice approach can be deployed in a powerful manner, but it must be studied deeply before it can be employed effectively in the analysis of politics.

Colomer's initial chapters, to illustrate, cry out for theoretical clarification. By my reading, Colomer is exploiting the tension among three basic axioms in collective choice theory: the independence of irrelevant alternatives, universal admissibility, and transitivity in collective choice. Had Colomer explicitly grounded his work upon axiomatic foundations, he could have communicated those tensions with far greater clarity. He also could have advanced his arguments with far greater power. For he then could have argued that Arrow's theorem (1951) provides insight into the possibility of democracy in two senses: its ability to operate as a coherent form of government but also its ability to exist, that is, to arise in the first place.

Cohen, too, could have cut deeper. Realizing that socially rational outcomes are attainable in prisoners' dilemma games through (certain forms) of repeated play, Cohen makes a series of thoughtful arguments as to why political cooperation was not achieved in Latin American democracies. But he fails to explore the full implications of the extended form. A more thorough analysis would have led him to pay closer attention to the militant's threat. What benefits would have justified the costs the militants would have had to pay, should they undermine the electoral prospects of their own political party? Put another way: Why would the moderates treat the militant's threats as credible? Recasting the game in extended form not only would have highlighted the significance of such questions but also would have underscored the significance of the institutional setting. In particular, it would have focused attention on the internal structure of the political parties; for it was the inability of the parties to defend and sustain their leaders' pledges that appears to have undermined the credibility of interparty agreements. Moving from the analysis of single plays of the game to an analysis of strategic behavior over time thus would have exposed missing portions of Cohen's account and led him to an even deeper investigation of the collapse of democracy.

A last slap on the wrist, or perhaps confession of bias: On the basis of the evidence of these books, the literature on collective action needs, I feel, structureindeed, much more structure. One way of making this point is by returning once again to the work of Cohen. As intimated above, insofar as Cohen's argument is correct, it then implies an internal party structure that renders party leaders unable to discipline militant followers. From where might this inability derive? By the reasoning of Cox and Rosenbluth (in Cowhey and McCubbins), party leaders in presidential systems face higher costs in achieving party unity than do those in parliamentary systems; and those who compete in open-list systems, which enable candidates to amass personal votes, confront higher costs than do those in closed-list systems. And, as shown by Geddes in The Politician's Dilemma (1994), the kinds of preference orderings studied by Cohen can be transformed to ones favoring cross-party cooperation, in certain competitive settings. 
Phrased narrowly, Cohen's account could have benefited from a closer analysis of the institutional and political setting of his actors. Phrased more broadly, the turn to rational choice has in part reflected a resistance to structuralist accounts; but, clearly, the two are complements, not substitutes, in the analysis of politics. It would appear that rational choice theory can, indeed, provide informative insights. But it appears best able to provide the foundations for scientific inquiry when applied to highly structured settings. It is perhaps for this reason that I come away from my reading finding my thinking most shaped by the work of Cowhey and McCubbins and Laver and Shepsle.

\section{REFERENCES}

Arrow, Kenneth. 1951. Social Choice and Individual Values. New Haven and London: Yale University Press.

Axelrod, Robert. 1986. "An Evolutionary Approach to Norms." American Political Science Review 80(4):1095-1111.

Bates, Robert H., Avner Greif, Margaret Levi, Jean-Laurent Rosenthal, and Barry Weingast. N.d. Analytic Narratives. Forthcoming.

Breton, Albert. 1964. "The Economics of Nationalism." Journal of Political Economy 72(4):376-86.

Collier, David, ed. 1979. The New Authoritarianism in Latin America. Princeton, NJ: Princeton University Press.

Cox, Gary. 1990. "Centripital and Centifugal Incentives in Electoral Systems." American Journal of Political Science 34(4):903-35.

Elster, Jon. 1989. Making Sense of Marx. Cambridge: Cambridge University Press.

Ferejohn, John. 1991. "Rationality and Interpretation: Parliamentary Elections In Early Stuart England." In the Economic Approach to Politics: A Critical Reassessment of the Theory of Rational Action, Ed. Kriston Renwick Konioe. NY: Harper Collins.
Geddes, Barbara. 1991. "Paradigms and Sand Castles in Comparative Politics." In Political Science, Looking to the Future, ed. William Crotty. Evanston, IL: Northwestern University Press.

Geddes, Barbara. 1994. Politician's Dilemma. Berkeley and Los Angeles: University of California Press.

Gellner, Ernest. 1979. Nations and Nationalism. Ithaca, NY: Cornell University Press.

Hardin, Russell. 1995. One for All: the Logic of Group Conflict. Princeton, NJ: Princeton University Press.

Huntington, Samuel P. 1991. The Third Wave. Norman and London: University of Oklahoma Press.

Inkeles, Alex. 1961. The Soviet Citizen. Cambridge, MA: Harvard University Press.

King, Gary, Robert Keohane, and Sidney Verba. 1994. Designing Social Inquiry. Princeton, NJ: Princeton University Press.

Lohmann, Susanne. 1994. "The Dynamics of Information Cascades: The Monday Demonstrations in Leipzig, East Germany, 19891991." World Politics 47(1):42-103.

O'Donnell, Guillermo. 1973. Modernization and Bureaucratic Authoritarianism. Berkeley: Institute of International Studies, University of California.

Olson, Mancur. 1977. The Logic of Collective Action. Cambridge, MA: Harvard University Press.

Przeworski, Adam. 1985. "Marxism and Rational Choice." Politics and Society 14(4):399-409.

Riker, William. 1982. Liberalism against Populism. Prospect Heights, IL: Waveland Press.

Sen, Amartya. 1982. Choice, Welfare, and Measurement. Oxford: Blackwell.

Schelling, Thomas. 1978. Micromotives and Macrobehavior. New York: W. W. Norton.

Skocpol, Theda. 1979. The State and Social Revolutions. Cambridge Cambridge University Press.

Taylor, Michael. 1987. The Possibility of Cooperation. Cambridge: Cambridge University Press.

Weiner, Myron, and Samuel P. Huntington. 1987. Understanding Political Development. Boston: Little-Brown. 